\title{
Investigating the Factors Affecting Working Capital of Companies Using the Generalized Method of Moments
}

\author{
Zeinab AzAMI ${ }^{1, *}$, Fozieh Jeyhoon TABAR ${ }^{2}$ \\ ${ }^{1}$ Faculty member of Accounting, Baft Higher Education Center, Shahid Bahonar University of \\ Kerman, Kerman, Iran \\ z.aazami@uk.ac.ir \\ ${ }^{2}$ Faculty member of Economic, Baft Higher Education Center, Shahid Bahonar University of \\ Kerman, Kerman, Iran \\ foziehjeyhoontabar@gmail.com
}

\begin{abstract}
This paper attempted to examine the determinants of investment level in working capital of companies listed on the Tehran Stock Exchange (TSE). For this purpose, data from 143 companies listed in the TSE were employed for 2004-2014. The generalized method of moments (GMM) was used to test the hypotheses. The findings suggested that in periods with lower GDP or lower corporate profitability, lower leverage, pre-period working capital and greater information asymmetry tended to make higher investment in working capital compared to other companies. In addition, there was no significant relationship between firm size, firm age and non-executives with corporate working capital.
\end{abstract}

Keywords: working capital, GMM, information asymmetry, GDP

\section{Introduction}

In all companies, whether large or small, the main purpose of accounting practices is to control critical departments, control the corporate performance and create hopes to improve performance. One of the main departments requiring appropriate control and management is the current assets and liabilities. In general, working capital management reflects the policies and decisions adopted on working capital for changing the various current assets and short-term financing sources [1]. Nowadays, working capital management refers to the management of resources and current expenditures to maximize shareholder wealth, which is crucial as part of the obligation of financial management [2].

Short-term funds are invested in current assets and the assets, which are both low-profitable and yet guaranteeing the company's liquidity. Therefore, it is necessary to determine the optimum level of assets.

In their study, Shyam-Sunder and Myers (1999) adopted the net increase in working capital as one of the factors contributing to the cash flow deficits, which can actually affect the debt

* Corresponding author. Tel: +98-344-242-6644, fax: +98-344-242-6633

E-mail address: z.aazami@uk.ac.ir 
incurred or repaid by the company [3]. Previous studies in this area show that leverage is also an important determinant in connection with the company's working capital ([4], [5], [6]) In addition, there are relevant studies upon which other features related to the company such as growth, profitability, corporate accessibility to capital markets, proportion of tangible assets, income fluctuations, firm age, operating cash flows, information asymmetry and even the Board directors are factors contributing to working capital [7].

Therefore, this study intended to determine the factors contributing to decisions made by the company to invest in working capital. It is essential to examine the factors contributing to working capital based on certain components of working capital [8]. Accordingly, the variables designed for this purpose should be able to measure the joint effects of all three components of working capital. Decision on the amount of investment in accounts receivable, inventory and the credit granted to suppliers of goods and services constitute the main components of working capital, known as cash conversion cycle. The cash conversion cycle refers to the time required between the purchase of raw materials and fundraising from the sales of goods. The longer the period, the larger the investment made in working capital and shorter the period the better the corporate liquidity position. That is why investment in working capital was examined in this study given the cash conversion cycle.

The findings could help investors better assess the working capital maintenance strategy. The results of this study demonstrated that different features of companies can justify the adoption of different appropriate methods of investment in working capital necessary for company's activity for special circumstances. The present study can contribute to better understanding as to why certain procedures are adopted by a company to maintain working capital as well as effective evaluation of corporate financial health.

This paper has been structured in a way that the next section will explore the theoretical framework, the literature review and research hypotheses. Then, the research methodology and statistical results are provided. The final section is dedicated to the interpretation of findings and conclusions.

\section{Theoretical framework and literature review}

Working capital management plays an important role in the growth and survival of any company. If the amount of investment in working capital is balanced against the total assets of the company, the sums might not have been used efficiently. Each of the components of working capital has its own costs and benefits. The inventory helps the management reduce the risk of running out of stocks and losing customers. It enables the company to cover the seasonal spikes in sales. On the one hand, the inventory in stock increases the cost of maintenance and warehousing. On the other hand, maintaining low inventory levels may lead to customer loss. In order to keep customers and avoid damaging the production process, it is essential to maintain a balanced inventory in each company. In connection with the company's accounts receivable, Salek (2005) raised two conflicting views: On the one hand, credit sales can enhance the sales rate, thus companies should not apply excessive tightening of credit sales. On the other hand, the 
increase in credit sales leads to bad debts, which ultimately leads to a decrease in sales rate [9]. Nonetheless, customers can be encouraged to pay off their debts ahead of schedule by granting discounts. The companies need to expand their debt volumes if the accounts payable are the lowest cost source of financing [10]. Hence, the working capital components should be analyzed according to their costs and benefits. And efficient management of working capital requires effective management of working capital components [7].

The problems concerning information asymmetry and agency costs affect financial choices of a company [7]. According to the theories of capital structure, Myers (1984) proposed the pecking order theory dealing with the role of information asymmetry in determining the amount of debt and capital. Based on the pecking order theory, companies need to reduce the negative signals through finance their resources internally. At the next stage to safe debts, they have to utilize the risky debts and equity [11]. According to this theory, since the company's leverage level is determined based on financial need, companies are not looking for a constant debt ratio. Once a company finds larger internal funds the company's leverage declines. As the trend persists, the excess cash to reduce costs arising from false choices are accumulated, while the funds can be used to pay the debt at maturity. Thus, working capital is a source of internal financing that can be used as an alternative to external financing. Nevertheless, the cost of external financing is extravagant for large companies due to floating costs and problems of information asymmetry in the market [12].

Higher amounts of working capital with a lower final value for the company allow the management to conveniently issue securities at the prices lower than real values, thereby to complete projects with positive net present values. Based on the arguments in pecking order theory, there is a strong relationship between investment in working capital and information asymmetry. Because of this relationship, companies have different characteristics in terms of profitability, growth opportunities, leverage, size, etc. with respect to the effectiveness of these features on the intensify or reduction of the problem of asymmetric information and the costs associated with the different methods in their level of investment in working capital [7].

In addition to the pecking order theory, the free cash flow hypothesis by Jensen (1986) expressed can be used to analyze the level of investment in working capital. This hypothesis stresses on agency costs related to free cash flow. According to this theory, managers increase the cash flow at their disposal in order to increase the amount of assets under control and gain power to decide on corporate investments [13]. Therefore, managers prefer to preserve a greater part of their cash in the form of working capital in order to reduce the risk of bankruptcy and investment. Hence this hypothesis emphasizes the importance of precautionary measures in cash holding [14]. The increase in working capital of companies makes it possible for managers to implement projects interesting, but not necessarily interesting to investors and shareholders. Because these projects are done using internal resources and there is no need for external financing [15], the managers of these companies are not supervised by capital markets [16].

Therefore, companies with high agency problems tend to hold more cash and use flexible procedures for working capital. In these companies, surplus cash flows are high and growth 
opportunities are low, without compelling the managers to distribute surplus funds for profit [17]. These companies may be too much abandoned for the collection of receivables and investments in inventory with their managers unwilling to release cash funds and make optimum utilization. As Jensen (1986) states, these companies are more likely to go through mergers and acquisitions with other companies. Opler et al. (1999) suggested that these companies are trying to keep large amounts of cash to protect themselves against unwanted mergers and acquisitions. These companies are difficult to price due to their high value of financial assets [16]. Hence, keeping too much cash and non-optimal investment in working capital can represent the poor quality of the company's management when judging investment opportunities ahead [7].

\section{Determinants of working capital level}

\section{Leverage}

Based on the pecking order theory, companies usually make long-term investments through internal financial resources due to the higher cost of external financing to reduce the supervision of shareholders [5]. Since the return of investment in capital is low, financing from external sources with the high cost of working capital cycle does not seem a good idea [4]. High levels of leverage in a company are probably due to the lack of internal funds. Hence, companies in such conditions need to pay more attention to the management of their working capital in order to avoid problems of fund deficit. Since they can use these funds for more efficient investment opportunities in the future, they need to avoid engaging their capital with the operating cycle of activities [18]. The negative relationship between leverage and working capital levels was approved in studies by Raheman and Nasr (2007), Zariyawati et al. (2009), Mathuva (2009) and Zariyawati et al. (2010)( [19]. [20], [21], [22].)

\section{Tangible assets}

Banos-Caballero et al. (2010) raised two different views about the relationship between tangible assets of the company and level of working capital. Due to lack of financial resources at the disposal of the company, investment in tangible assets reduces the level of investment in the company's working capital. On the other hand, companies enjoying greater tangible assets tend to have more agency problems because of the valuation of these assets. Therefore, the level of working capital in the company is likely to be higher [4].

\section{Firm life}

Younger companies tend to have greater growth opportunities, and the company grows more steadily at ages. Therefore, it is expected that companies with higher age have greater working capital due to reduced growth rates [5]. On the other hand, as the company ages, it can curtail its working capital according to the company's experience in relation to managing inventory and customer relations. Due to a combination of effects from improved working capital management and a negative relationship between growth rate and age, it can be expected that the relationship between the company's life and the level of working capital both have positive and negative patterns [7]. 


\section{Profitability}

The results of previous research on the relationship between corporate profitability and the level of working capital are different. On the one hand, due to the fact that financing is easier for profitable companies, is it possible for these companies to keep the cash funds at minimal [5]. The results from the majority of previous studies proved there is a negative correlation between the level of working capital and corporate performance ([23], [24], [25], [26] [27], [28], [29], [30], [31]).

On the other hand, Nazir and and Afza (2008) argued that because the executives of profitable companies have sufficient cash to invest in projects at their disposal, there are no concerns regarding the lack of working capital. Therefore, there is a significant positive relationship between the level of working capital and corporate performance. The results of Hill et al. (2010) also confirm this positive relationship.

\section{Firm size}

In larger companies, managers are abler to manage their working capital and tend to diversify activities. Larger companies gain access to the capital market more conveniently [5]. These companies benefit from greater bargaining power with suppliers and customers ([4], [32]). Hence, it is expected there is a negative relationship between firm size and the level of working capital. The results obtained by Chiu et al. (2006), Nazir and and Afza (2008) and Zaryavati et al. (2010) confirm this negative relationship.

On the other hand, larger companies curtail information asymmetry because they are under the supervision of analysts, while external financing is easier owning to fewer restrictions for these companies. Hence, larger companies enjoy greater freedom in working capital management than small companies, requiring greater working capital due to high volume of sales [32].

\section{Economic conditions}

Evidence suggests that macroeconomic factors such as GDP affect commercial credits and inventory investment. Under economic downturn and financial crisis, companies are under intense pressure in terms of liquidity, and cash flows become a scarce resource by the harsh conditions in the credit market and reduced market demand. The company under such circumstances may reduce the level of working capital to provide the cash necessary to carry out activities [4]. On the other hand, the company may not be able to develop its operations and activities uniformly in periods of economic downturn, and may even face several problems in relation to the sale of inventory, collection of receivables and payment of debts. Company's management in this situation would increase the working capital levels in order to ensure the daily operations run smoothly [5].

\section{Information asymmetry}

In companies with high information asymmetry, it is more difficult than other companies to evaluate projects and cash flow. Hence, the market expects these companies to achieve higher returns [8]. Because the increasing information asymmetry between creditors and shareholders escalates the cost of external financing, pecking order theory argues that such companies first 
finance their resources internally and then resort to external resources. Banos et al. (2010) argued that companies with high growth opportunities tend to have higher information asymmetry. Since the valuation of these companies is mainly based on the future growth opportunities, working capital is low due to the need for internal financing resources.

\section{Board characteristics and independence}

More independent of the Board of Directors will bring about better oversight of managers, which in turn leads to lower cash conversion cycle [7]. On the other hand, some research associates the role of non-executives with rubber stamps [33], putting an emphasis on independent executive management.

This study involved the ratio of non-executives to the total members of the Board of Directors in order to assess the Board's independence. However, it is still a mysterious exactly how independence of the Board affects working capital management.

\section{Hypotheses}

According to the theoretical foundations of the research, the study hypotheses were formulated as follows:

Hypothesis 1: There is a significant relationship between the ratio of working capital of prior period and the level of working capital of current period.

Hypothesis 2: There is a significant relationship between financial leverage and the level of working capital of companies.

Hypothesis 3: There is a significant relationship between the ratio of tangible assets and working capital of companies.

Hypothesis 4: There is a significant relationship between the age and level of working capital of companies.

Hypothesis 5: There is a significant relationship between the company profitability and level of working capital.

Hypothesis 6: There is a significant relationship between the firm size and level of financial leverage.

Hypothesis 7: There is a significant relationship between economic conditions (GDP) and level of working capital of companies.

Hypothesis 8: There is a significant relationship between the level of information asymmetry and level of working capital of companies.

Hypothesis 9: There is a significant relationship between the non-executive directors and level of working capital of companies.

\section{Methodology}

As a quasi-experimental study, this research is correlational in terms of the method used and is applied in terms of the objectives. In order to test the hypotheses, Generalized Method of Moments (GMM) was used. The required data were collected using information from databases of Tehran Stock Exchange as well as databases such as Tadbirpardaz, software, financial 
statements, and explanatory notes. Moreover, data analysis was performed using Eviews software.

\section{Sample}

The study population consisted of all companies active in the stock and listed on Tehran Stock Exchange from 2003 to 2014. To select a sample statistically representative of the target population, an elimination method was used. For this purpose, the following criteria were considered and, if a company met all the criteria, it would be selected as one of the sample companies. The criteria were as follows:

A) The company was accepted in Tehran Stock Exchange before 2003.

B) The company was not in the group of financial intermediation companies.

C) The fiscal year of the companies was at the end of $29^{\text {th }}$ March of each year.

D) The companies' shares were traded on the stock exchange. (Their activities were not interrupted. In so doing, companies that were not trading for at least four months were excluded from the study).

E) The data needed to conduct the research were available in the years under study.

Finally, according to the above criteria, 143 qualified companies were chosen as the study sample.

\section{Research model and variables}

In this study, the Generalized Method of Moments (GMM) was used to test the hypotheses. As previously explained, in general, this study sought to investigate the factors affecting the working capital of companies. In order to measure the working capital of a given company, the company's cash conversion cycle was used which provides the decision makers with the decision on the rate of investment in accounts receivable and inventory and the amount of credit from suppliers of goods and services. The use of cash conversion cycle is useful because it identifies not only the expectations with regard to each of the elements that make up the working capital, but also the fact that production, distribution, and collection of receivables do not occur at the same time but relative to each other and with time lag. In this regard, other studies have used the cash conversion cycle, including the studies conducted by Deloof (2003), Lazaridis and Tryfonidis (2006) Garcia-Teruel and Martinz-Solano (2007), and Gill et al. (2010) ([25], [34], [26], [35]). Cash conversion cycle is defined as follows:

Cash conversion cycle $=($ receivables collection period + inventory turnover period $)$ - payment of debt period

Receivable Turnover period $=($ receivable accounts $/$ sale $) * 365$

Inventory turnover period $=($ inventory $/$ cost of goods sold $) * 365$

Debt payment period $=($ payable accounts $/$ sale $) * 365$

Accordingly, the study model has been formulated as follows:

$$
\begin{gathered}
\operatorname{CCC}_{i, \mathrm{t}}=\beta_{1} \operatorname{CCC}_{\mathrm{i}, \mathrm{t}-1}+\beta_{2} \mathrm{LEV}_{\mathrm{i}, \mathrm{t}}+\beta_{3} \mathrm{TANG}_{\mathrm{i}, \mathrm{t}}+\beta_{4} \mathrm{AGE}_{\mathrm{i}, \mathrm{t}}+\beta_{5} \text { PROFIT }_{\mathrm{i}, \mathrm{t}}+\beta_{6} \mathrm{SIZE}_{\mathrm{i}, \mathrm{t}} \\
+\beta_{7} \mathrm{LN}(\mathrm{GDP})_{\mathrm{i}, \mathrm{t}}+\beta_{8} \mathrm{QS}_{\mathrm{i}, \mathrm{t}}+\beta_{9} \mathrm{NED}_{\mathrm{i}, \mathrm{t}}
\end{gathered}
$$


Where the operational definitions of variables used are as follows: $\mathrm{CCC}_{\mathrm{i}, \mathrm{t}-1}=$ Cash conversion cycle of prior period

$\mathrm{LEV}_{\mathrm{i}, \mathrm{t}}=$ the ratio of leverage in the prior year to leverage calculated by dividing the total debt to total assets.

$\mathrm{TANG}_{\mathrm{i}, \mathrm{t}}=$ Tangible assets ratio obtained by dividing the gross value of property, plant and equipment to total book value of assets

$\mathrm{AGE}_{\mathrm{i}, \mathrm{t}}=$ Age of the company

PROFIT $_{\mathrm{i}, \mathrm{t}}=$ Stock returns

$\operatorname{SIZE}_{i, t}=$ Firm size which is the natural logarithm of the company's assets.

$\mathrm{LN}(\mathrm{GDP})_{\mathrm{i}, \mathrm{t}}=$ The natural logarithm of GDP

SIZE = natural logarithm of total assets

$\mathrm{NED}_{\mathrm{i}, \mathrm{t}}=$ the ration of non-executive directors obtained by dividing the number of non-executive directors by the company's managers.

$\mathrm{QS}_{\mathrm{i}, \mathrm{t}}=$ Tobin's Q index

Tobin's Q index is obtained from the following equation:

$$
Q_{S}=\frac{\text { VOCSILOY }+ \text { EMVOPSILOY +BVLTLILOY }+ \text { BVCLILOY }}{\text { BVTALOY }}
$$

VOCSILOY = market value of equity at the end of the year

EMVOPSILOY = estimated market value of shares outstanding at the end of the year

BVLTLILOY = book value of long-term debt at the end of the year

BVTALOY = book value of total assets at the end of the year

The value of EMVOPSILOY in the companies listed on Tehran Stock Exchange is zero due to the lack of preferred stock.

In this study, to estimate the model, GMM was used. GMM is an appropriate econometric method to solve or reduce the endogenous problem of explanatory variables.

Using dynamic panel data GMM technique has several advantages, such as considering individual heterogeneity and more information, and removing the existing bias in cross-sectional regressions, resulting in more accurate estimates, with higher efficiency, and lower co-linearity using interrupted dependent variables. Dynamic panel data GMM method is used when the number of cross-cutting variables $(\mathrm{N})$ is greater than the number of years and time $(\mathrm{T})$ i.e. $(\mathrm{N}>\mathrm{T})$ which is the case in this paper too i.e. the number of sections (companies) is more than the number of time (years) [36].

In general, dynamic GMM method has advantages over other methods as follows:

In this research, GMM was used to estimate the model. For ensuring the appropriateness of using this method to estimate the model, two tests are used. One of these tests is Sargent test which is used to prove the requirement of Valid over Identifying restrictions i.e. the accuracy and 
validity of instrumental variables. The second test is the correlation tests of AR (1) and AR (2). This test is also used to check the validity and accuracy of instrumental variables. Arellano and Bond (1991) maintain that in the estimation of GMM, residuals should have the first order serial correlation of AR (1) but not the second-order serial correlation of AR (2).

Table 1: The results of the model estimation of GMM

\begin{tabular}{|c|c|c|c|}
\hline Variable & coefficient & t-statistic & Significance \\
\hline$C C C(-1)$ & $0.167^{* * *}$ & 5.753 & 0.000 \\
\hline$L E V$ & $-0.706^{* *}$ & -2.319 & 0.020 \\
\hline TANG & $1.168^{*}$ & 1.810 & 0.070 \\
\hline AGE & 0.833 & 1.167 & 0.243 \\
\hline PROFIT & $-0.014^{* *}$ & -2.067 & 0.039 \\
\hline SIZE & 0.124 & 0.684 & 0.494 \\
\hline$L N(G D P)$ & $-0.858^{* * *}$ & -2.764 & 0.005 \\
\hline$Q_{S}$ & $0.137^{* *}$ & 2.015 & 0.044 \\
\hline NED & 0.316 & 0.524 & 0.600 \\
\hline $\begin{array}{l}\text { AR (1) } \\
\text { P-value }\end{array}$ & \multicolumn{3}{|c|}{0.0003} \\
\hline $\begin{array}{l}\text { AR (2) } \\
\text { p-value }\end{array}$ & \multicolumn{3}{|c|}{0.451} \\
\hline $\begin{array}{c}\text { Sargent test } \\
\text { p-value }\end{array}$ & \multicolumn{3}{|c|}{0.215} \\
\hline \multicolumn{4}{|c|}{$\begin{array}{l}* * *, * *, * \text { Represent } 1 \text { percent, } 5 \text { percent and } 10 \text { percent significance, } \\
\text { respectively. }\end{array}$} \\
\hline
\end{tabular}

\section{Testing the study hypotheses}

The results of the model fit are given in Table 1 . In this table, positive (negative) numbers in the column of coefficient of the variables indicate the direct correlation (inverse) of each variable with the financial leverage of the companies under study.

The first hypothesis examined the relationship between the level of working capital of the prior period and working capital of the current period of a given company. According to Table 1, given the significance of t-statistic for the variable CCC (-1) (t-statistic 5.753) and positive the estimated coefficient for this variable (0.167), it can be concluded that there is a positive and significant relationship between working capital of prior period and the level of working capital of the current period. Accordingly, the first hypothesis is accepted at $99 \%$ confidence level.

The second hypothesis examined the relationship between financial leverage and working capital of the companies. given the significance of t-statistic for the variable LEV (t-statistic -2.319) and negative estimated coefficient for this variable (-0.706), it can be concluded that there is a negative and significant relationship between financial leverage and working capital of the companies at 95\% confidence level. The negative relationship between the level of leverage and working 
capital is in line with the concepts discussed in pecking order theory. Based on pecking order theory, only if a company does not have sufficient sources of internal financing, it turns to be funded through debt. The increase in liabilities means that the repayment of debt results in the reduction of the capital available to perform daily activities and future investment objectives and thus forces the company's management to efficiently use its working capital. Finally, the conditions can reduce the investment in working capital for the company [7]. Moreover, given that the cost of financing through debt is more than returns from investments on liquidated assets, a company enjoying a high level of leverage invests less of its capital in working capital [4]. These results are consistent with the findings of studies conducted by Nazir and Afza (2009), BanosCaballero et al (2010), Chiou et al (2006), Mathuva (2009), Raheman and Nasr (2007), and Zariyawati et al (2009).

The third hypothesis examined the relationship between the ratio of fixed assets to the company's working capital. According to Table 1, given the significance of t-statistic for the variable TANG (t-statistic 1.810) and positive the estimated coefficient for this variable (1.168), it can be concluded that there is a positive and significant relationship between the ratio of fixed assets and the company's working capital. Accordingly, the third hypothesis is accepted at $90 \%$ confidence level. The results of testing this hypothesis are in line with the investigation done by Banos- Caballero et al (2010).

The fourth hypothesis examined the relationship between age and the company's working capital. According to Table 1, given the significance of t-statistic for variable AGE (t-statistic 1.167), no significant relationship was found between age and level of working capital.

The fifth hypothesis examined the relationship between corporate profitability and company's working capital. According to Table 1, given the significance t-statistic for the variable PROFIT (t-statistic -2.067) and negative estimated coefficient for this variable $(-0.014)$, it can be concluded that there is a negative and significant relationship between t stock returns as a measure to evaluate profitability in the research and the company's working capital at 95\% confidence level. The results of testing this hypothesis are in line with the research conducted by Beaumont, and Begemann (1997); Bhattacharyya and Raghavacahari (1977); Deloof (2003); Garcia- Teruel and Martinez- Solano (2007); Ghosh and Maji (2004); Narware (2004), Shin and and Soenen (1998); Soenen (1993); and Talha et al. (2010).

The sixth hypothesis dealt with the relationship between firm size and the level of working capital. According to Table 1, given the significance of t-statistic for the variable SIZE (t-statistic 0.684), there is no significant relationship between the firm size and level of working capital.

The seventh hypothesis examined the relationship between GDP and the company's working capital. According to Table 1, given the significance of t-statistic for the variable Ln (GDP) (tstatistic -2.764$)$ and negative estimated coefficient for this variable $(-0.858)$, it can be concluded that there is a negative and significant relationship between GDP and working capital at 99\% confidence level. The results of testing this hypothesis are consistent with those of the research conducted by Zariyawati and colleagues (2010). 
The eighth hypothesis examined the relationship between Tobin's Q ratio and the company's working capital. According to Table 1, given the significance of t-statistic for the variable $\mathrm{Q}_{\mathrm{s}}(\mathrm{t}-$ statistic 2.015) and positive estimated coefficient for this variable (0.137), it can be concluded that there is a positive and significant relationship between Tobin's Q ratio and working capital. The obtained results confirm the fact that in companies with high information asymmetry, the evaluation of long-term projects and cash flows are more difficult than others. Therefore, in compliance with pecking order theory due to the high cost of external financing, these companies try to initially use their local resources to provide their needed funds [8].

The ninth hypothesis examined the relationship between the ratio of non-executive directors and the company's working capital. According to Table 1, given the significance of t-statistic for the variable NED (t-statistic 0.524), it can be concluded that there is no significant relationship between NED and working capital. In their study, Zariyawati et al (2010) found a trivial relationship between these two variables and the volume of investments in working capital to companies operating in Malaysia. The existence of a trivial relationship in these conditions could mean that the issues of working capital management are probably of no importance for the board and as a result, the decisions taken by the board had not affected the level of investment in working capital of these companies.

As seen in Table 1, Sargent test statistic which enjoys over- identifying restrictions from $\lambda^{2}$ distribution with equal degrees of freedom, does not reject the null hypothesis i.e. noncorrelation of the residuals with instrumental variables ( valid tool); therefore, it can be said that the results are valid. AR (2) has a null hypothesis based on the lack of autocorrelation. As the above evidence shows, the test results reject the existence of autocorrelation.

\section{Conclusion}

Poor performance of working capital management in companies in Iran as well as the companies' liquidity problems during the past few years has created questions about the possible causes of these conditions. Accordingly, this study aimed to understand the factors affecting the level of working capital in the companies listed on Tehran Stock Exchange. In this study, data from 143 companies over a period of 12 years (from 2003 to 2014) were used to investigate the relationship between enterprise features and also features of the board and the company's working capital. The research findings indicate that in periods with lower GDP, the level of working capital of companies is higher. Also, firms with lower profits have lower leverage level, higher level of working capital in the prior year, and further information asymmetry, and more investment in working capital compared with other companies. In addition, no significant relationship was found between the firm size and age and the ratio of non-executive directors of companies and the level of working capital.

The findings of this research will help investors in evaluating the company's strategy of working capital holdings. The results of this study show that different features of companies can justify the necessity of the use of different methods of working capital appropriate for special circumstances. Thus, the present study can be used to better understand the reasons for certain 
procedures and maintenance of a company's working capital and effectively help the process of evaluating the financial health of companies. It is clear that in this regard there may be other factors that can affect the procedure of choice for the level of working capital of companies. In this way, more studies are required in this area considering the other features of the companies' activities or even the determining factors. In addition, it is necessary to analyze the differences related to the maintenance procedures of working capital of companies operating in different countries according to the specific circumstances of their operation, such as financial systems. For example, bank activity-based financial systems can be compared with the market activitybased financial system (7). Although a bulk of studies have so far examined the effects of management practices and working capital on profitability, there is a dearth of research on the impact of these issues on firm value. Therefore it is necessary to examine the impact of investment procedures in working capital on firm value and compensate for the lack of research literature in this area.

\section{References}

1. Izadi Nia, N., Taki, A. (2010). The effect of working capital management on the viability of companies listed on the Tehran Stock Exchange. Quarterly Financial Accounting, Vol 2. No 5, pp 120-139.

2. Areias, P.M.A., Belytschko, T. (2005). Analysis of Three-Dimensional Crack Initiation and Propagation Using the Extended Finite Element Method. International Journal for Numerical Methods in Engineering, Vol. 63. No. 55, pp 760-788.

3. Shyam-Sunder, L., Myers, S.C. (1999). Testing static tradeoff against pecking order models of capital structure, Journal of Financial Economics, Vol.51, pp187-221.

4. Banos-Caballero, S., Garc1'a-Teruel, P.J., Martı'nez-Solano, P. (2010). Working capital management in SMEs. Accounting and Finance, Vol.50, pp511-527.

5. Chiou, J.R., Cheng, L., Wu, H.W. (2006). The determinants of working capital management. Journal of American Academy of Business, Vol.10, No.1, pp149-155.

6. Kargar, J., Blumenthal, R.A. (1994). Leverage impact on working capital in small businesses. TMA Journal, Vol.14, No.6, pp. 46-51.

7. Shaista, W., and Veeri C. A. (2013). Determinants of Working Capital Investment: A Study of Malaysian PublicListed Firms. Australasian Accounting Business and Finance Journal, Vol. 7, No. 2, pp. 63-83.

8. Hill, M.D., Kelly, G.W., Highfield, M.J. (2010). Net operating working capital behavior: A first look, Financial Management, Vol.39, No.2, pp.783-805.

9. Salek, J.G. (2005). Accounts Receivable Management Best Practices, John Wiley and Sons, New Jersey.

10. Berk, J., DeMarzo, P., Harford, J. (2009). Fundamentals of Corporate Finance, Pearson Education Inc, Boston.Wasiuzzaman and Arumugam | Determinants of Working Capital Investment 81

11. Myers, S.C. (1984). The capital structure puzzle, Journal of Finance, Vol.39, pp.572-592.

12. Fazzari, S.M., Petersen, B. (1993). Working capital and fixed investment: new evidence on financing constraints, Rand Journal of Economics, Vol.24, pp.328-342.

13. Ferreira, M.A., Vilela, A.S. (2004). Why do firms hold cash? Evidence from EMU countries, European Financial Management, Vol.10, No.2, pp. 295-319. 
14. Opler, T., Pinkowitz, L., Stulz, R. Williamson, R. (1999). The determinants and implications of corporate cash holdings. Journal of Financial Economics, Vol.52, No.1, pp.3-46.

15. Jensen, M. (1986). Agency costs of free cash flow, corporate finance and takeovers. American Economic Review, Vol.76, pp.323-329.

16. Pinkowitz, L. (2000). The market for corporate control and corporate cash holdings, Working Paper, Georgetown University, January 2000.

17. Bates, T.W., Kahle, K.M., Stulz, R.M. (2009). Why do U.S. firms hold so much more cash than they used to?, The Journal of Finance, Vol.64, No.5, pp.1985-2021.

18. Nazir, M.S. and Afza, T. (2009). Impact of aggressive working capital management policy on firms' profitability. The IUP Journal of Applied Finance, Vol.15, No.8, pp19-30.

19. Raheman, A., Nasr, M. (2007). Working capital management and profitability - Case of Pakistani firms', International Review of Business Research Papers, Vol.3, No.1, pp.279-300.

20. Zariyawati, M. A., Annuar, M. N., Taufiq, H. and Rahim, A. S. A. (2009). Working capital management and corporate performance: Case of Malaysia. Journal of ModernAccounting and Auditing, Vol.5, No.11, pp. 47-54.

21. Mathuva, D.M . (2009), Influence of working capital management components on corporate profitability: A survey on Kenyan listed firms, Research Journal of Business Management, Vol.3, pp1-11.

22. Zariyawati, M. A., Taufiq, H., Annuar, M. N., Sazali, A.( 2010). Determinants of Working Capital Management: Evidence from Malaysia, in Financial Theory and Engineering: Proceedings of the 2010 International Conference, Dubai, UAE, 18 -20 June 2010, IEEE Computer Society Press, pp. 190-194.

23. Beaumont, S.M., Begemann, E. (1997). Measuring associations between working capital and return on investment. South African Journal of Business Management, Vol.28, No.1, pp1-5.

24. Bhattacharyya, S.K. Raghavacahari, M. (1977). Determinants of effective working capital management - A discriminant analysis approach, Working Paper, Indian Institute of Management, March 1977.

25. Deloof, M. (2003), Does working capital management affect profitability of Belgian firms?. Journal of Business Finance and Accounting, Vol.30, No.3-4, pp. 573-587.

26. Garcia-Teruel, P.J., Martinez-Solano, P. (2007), Effects of working capital management on SME profitability. International Journal of Managerial Finance, Vol.3, No.2, pp164177.

27. Ghosh, S.K., Maji, S.G. (2004). Working capital management efficiency: A study on the Indian cement industry. Management Accountant, Vol.39, No.5, pp363-372.

28. Narware, P.C. (2004). Working capital and profitability-An empirical analysis. Management Accountant, Vol.39, No.6, pp 491-493.

29. Shin, H.H., Soenen, L. (1998). Efficiency of working capital management and corporate profitability. Financial Practice and Education, Vol.8, No.2, pp.37-45.

30. Soenen, L.A. (1993). Cash conversion cycle and corporate profitability. Journal of Cash Management, Vol.13, No.4, pp.53-57.

31. Talha, M., Christopher, S. B., Kamalavalli, A. L. (2010). Sensitivity of profitability to working capital management: a study of Indian corporate hospitals. International Journal of Managerial and Financial Accounting, Vol.2, No.3, pp. 213-227.

32. Moussawi, R., LaPlante, M., Kieschnick, R., Baranchuk, N. (2006). Corporate working capital management: Determinants and consequences. Working Paper, Baylor University, November 2006. 
33. Cornforth, C. ( 2002), Making sense of co-operative governance: Competing models and tensions, Review of International Co-operation, Vol.95, No.1, pp51-57.

34. Lazaridis, I., Tryfonidis, D. (2006), Relationship between working capital management and profitability of listed companies on the athens stock exchange. Financial Management Anal, Vol.19, No.1, pp. 26-35.

35. Gill, A., Biger, N., Mathur, N. (2010). The relationship between working capital management and profitability: Evidence from the United States. Business Economics, Vol.10, pp.1-9.

36. Baltagi, B. H. (2005). Econometric Analysis of Panel Data., Third edition, John Wiley and Sons Ltd. 